\title{
Investigation of Democracy Education in Turkish Primary Schools
}

\author{
Asım Ar \\ Prof. Dr., Eskişehir Osmangazi University, Faculty of Education, Turkey, ari@ogu.edu.tr \\ Özgür Sirem \\ Dr., Ministry of Education, Board of Education and Discipline, Turkey,dr.ozgursirem@gmail.com
}

Gökhan Kayır

Dr., Ministry of Education, Eskisehir Regional Directorate of Education, Turkey, gokhankayir@gmail.com

\begin{abstract}
The purpose of this study is to identify teacher opinions about democracy education at primary schools in Turkey. The research is designed as a single case study. The study group was selected with an purposive cum convenience sampling method and consists of 15 teachers working at a primary school in Ankara, Turkey. The data were gathered with a semi-structured interview form that is developed by researchers. The data were coded by different coders and analyzed with the descriptive analysis method. Findings show that teachers don't get any formation on teaching democracy both during their university years and through in-service training during their professional life. The teachers also share the opinion that the activities in the curricula and books are not enough. Democracy education should be given with concrete activities that are also suitable for the students' level. The teachers state that they do democracy education activities in their lessons. It is concluded from the research that democracy education activities should have more place in the curricula and thereupon course books, teacher candidates and the teachers should get more and applied courses and training, also teachers should give more place to structured and expedient democracy education activities in their lessons.
\end{abstract}

Keywords: democracy education, primary school teachers, primary school students, democracy, primary school

\section{INTRODUCTION}

To catch the rhythm of the everchanging world and reach high democratic and civic standards, countries should first emphasize the education of individuals. Democracy education aims to set up a common democracy conscience by making democratic behaviors permanent (Dewey, 1996; Tourain, 2002). Raising an individual with high quality means at the same time transmitting that individual to moral maturity. A good education leads a good future of an individual and its nation (Blair, 2003; Carslon, 2005). For this reason, It can be said that an effective and well-equipped learning environment should be experienced by the students. Because a nation's and a country's happiness and prosperity directly depend on its educating it's future grown-up citizens well. To provide that countries should value their individuals and should prepare them for the future. The education should be formed in a way that any individual should improve his personality and defend the rights of himself, his family, and his society (Davis, 2003). The concept of defending rights becomes more inherent and lasting when it is adopted at young ages (Dewey, 1996). Democracy education in the schools directly affects the daily life of the children and directs them. Knowing his rights and responsibilities and 
defending himself by using these rights are expected behaviors from a healthy citizen (Ersoy, 2016; Morin, 2006). Such an individual contributes to the democratic environment of his society positively. He will be a good role model by defending and improving human rights (Gözütok, 2007), as human rights and democracy conscience are a subsidiary of one another (Özdemir, 1996).

The government is responsible not only for conducting managerial and political parts of the democracy but also for providing democratic sustainability and developing human relations (Dewey, 1996). Democracy conscience should be the final aim of education systems in the developed nations to educate individuals who are aware of their responsibilities and political roles, foresee the results of their behaviors and internalize democracy (Levin, 1998; Morin, 2006).

All the education systems aim to make an individual a good member of the country and the rest of the world. Schools have some important functions as maintaining traditions, transferring historical and cultural values to the new generations, and preparing children and young for the real world (Turkish Ministry of National Education, 2015). In addition, teaching democratic life culture and democratic values are seen among schools' and curriculums' main functions (Davis, 2003; Blair, 2003). With the help of this kind of education in schools, a healthy generation can be raised. Ersoy (2007) states that all institutions of a country should work in harmony and share a common goal if an effective generation is desired. While Sağlam (2011) explains the role of the school as the preparer the children to the community life. Carlson (2005) considers the schools as the most important factor to teach democratic attitudes and skills to the children. Thus schools should be the main channel to transmit democratic values to the children during their school life.

The best way to achieve a successful democracy education is to provide settings in which a democratic lifestyle can be performed easily. Such a setting demands interaction among all the parties in the school such as teachers, managers, students, parents, etc. (Dewey, 1996). The present school settings should be transformed in a form that will support students ' democratic lifestyles. Levin (1998) lists the characteristics of a democratic school as:

- Everyone should be respectful and tolerant of different opinions, the views of others should be respected,

- School people should try to understand those on the other side.

- Active participation in decision-making processes at school should be ensured.

- School environments should be able to raise awareness of solidarity and community,

- Everyone at the school should be able to comment on the practices at the school.

Teachers' functions by creating a democratic classroom environment based on respect, love, and tolerance play an important role in children's adapting and showing democratic behaviors. First of all, teachers must demonstrate these behaviors themselves. Of course, it can be said that teachers should include activities that will support democratic education in their classrooms and make students adopt concepts such as rights and justice. Richardson (1979) stated that a democratic classroom should have the following characteristics:

$\square$ Ensuring that students respect and trust others,

$\square$ Giving students some responsibilities in the management of the course and the classroom,

$\square$ Improving students' self-confidence by rewarding their achievements,

$\square$ Students see that democratic values (rights, justice, freedom, etc.) are implemented in school and the classroom and that they are valued, 
Problems should be approached in a solution-oriented manner at school or in the classroom.

Before the middle school and high school period when the personality characteristics of the individual are formed, it is necessary to teach children the knowledge, skills and values related to democracy in primary schools and to contribute to the internalization of this awareness. The individual should be able to continue his life within the framework of respect and love without excluding his disabled friend, marginalizing his / her different friends. To do this, the consciousness of democracy must be developed in the individual and the concept of human rights must be learned in detail. With the development of awareness of democracy in the individual, mutual respect and love will be established. At the same time, the awareness of democracy will enable the individual to choose understanding and mutual communication instead of insulting or fighting in a conflict. As a society, we need to support and reward such behavior. These behaviors are the values that should be taught first in primary schools. Özdemir (1998) stated that providing children with theoretical knowledge as well as skills and values they will use in practice should be the priority of primary schools.

In this context, democratic awareness to be created in primary schools will contribute to children knowing their rights and responsibilities, to defend themselves, to protect themselves, and most importantly, to learn about human rights. First of all, to develop an awareness of democracy within children, it should be ensured that teachers take responsibility in this regard, and they should be assigned tasks. Teachers are expected to teach and develop the awareness of democracy in children. It is thought that this research will guide teachers towards the education of democracy in primary schools and will also contribute to human rights and democracy education and social studies lessons. Within the scope of the research, it is thought that benefiting from the opinions of the teachers, will contribute to future research in terms of conducting the democracy education lessons in primary schools effectively and following its purpose.

In this context, the study aimed to determine the teachers' views on democracy education in primary schools. For this purpose, the following questions were sought.

1. Is democracy education included in education faculties?

2. Is democracy education included in in-service training?

3. Is democracy education included in the primary school curriculum?

4. What are the activities teachers do in their lessons on democracy education?

5. What is done about democracy education outside of the lesson?

6. What are the examples of activities for the democracy education framework program?

\section{METHOD}

\section{Research Design}

This qualitative study was designed as a case study. Qualitative research provides a holistic and realistic presentation of the events and thoughts in which qualitative data collection methods such as interview, document analysis, and observation are used (Yıldırım, 1999). Case studies, on the other hand, are based on the 'how' and 'why' questions, but allow the researcher to examine a phenomenon or event that cannot be controlled in depth. Since the situations are different from each other, there is no generalization of the results, and the results collected for a situation are expected to create experiences and examples for understanding similar situations (Bogdan \& Biklen, 1992; Yıldırım \& Şimşek, 2016).

\section{Study Group}


The research was carried out with 15 primary school teachers in a primary school in the city center of Ankara, where 35 teachers work. In this study, the participants; have different characteristics in terms of grade levels (1st, 2nd, 3rd and 4th-grade levels), gender (10 females, 5 males) and seniority characteristics (1-7, 8-15, 16-23 and 24 and above seniority) Similar aspects of the cases analyzed by teachers were determined. The opinions of teachers from all grade levels and working in primary school were obtained, the most information about democracy education was tried to be reached. In studies, it is necessary to focus on different views and to identify similar aspects from the difference (Liamputtong, 2013; Morgan \& Morgan, 2008). In this respect, the researcher primarily focused on different views and formed the themes, categories and codes of similar aspects from the difference. The characteristics of the teachers who make up the study group are given below

Table 1

Information about the study group

\begin{tabular}{lllll}
\hline Total Number of Teachers: 15 & \multicolumn{2}{c}{ Female } \\
\cline { 2 - 5 } Gender & \multicolumn{3}{c}{ Male } & \multicolumn{1}{c}{5} \\
\hline Experience & $1-7$ & $8-15$ & $16-23$ & 24 and more \\
\cline { 2 - 5 } & 2 & 4 & 6 & 3 \\
\hline Class level & $1^{\text {st }}$ Class & $2^{\text {nd }}$ Class & $3^{\text {rd }}$ Class & $4^{\text {th }}$ Class \\
\cline { 2 - 5 } & 2 & 4 & 5 & 4 \\
\hline
\end{tabular}

Looking at Table 1, a total of 15 primary school teachers, 10 female and 5 male, participated in the study. Two of the primary school teachers participating are $1-7$, four are $8-15$, six are $16-23$, and three are teachers with a seniority of 23 and above. Looking at the grade level of the teachers, two from the 1 st grade, four from the 2 nd and 4 th grade, and five from the 3rd grade take part in the study.

\section{Collection of Data}

The data were collected using interview forms to determine the status of education of democracy to primary school students according to the opinions of primary school teachers. Although a certain level of standardization and flexibility in interviews allows providing detailed information on a specific subject, it is frequently used by researchers in terms of eliminating the limitations in questionnaires (Yıldırım \& Şimşek, 2016). Interviewing, which is expressed as collecting data from relevant persons within the framework of the questions that are sought in research, provides in-depth information about a specific research topic or a question (Büyüköztürk et al., 2009). Semi-structured research questions used to obtain data were developed by researchers. Initially, interview questions consisting of 25 items were prepared by literature review. This interview form was examined by 4 academicians ( 1 curriculum \& teaching, 1 Turkish education, 1 social studies education and 1 classroom education). The questions were rearranged in line with the suggestions given, and the interview form consisted of 12 questions and gave its final form. The Interview questions were clear enough for the participants.

Interviews with primary school teachers were held in March 2020. Before the interviews were made with the teachers, preliminary interviews were made and the contributions and purpose of the study were explained. Open-ended interview questions prepared were asked to the participants. Attention was paid to answering the research questions in environments where teachers felt comfortable and were analyzed by the researchers. The answers given by the teachers were taken by the researchers by writing in the form of taking notes on the interview form. The responses given after the interview with the teachers were immediately arranged and shared with the teacher who was interviewed. Teachers were asked whether there was any information they wanted to add, and final corrections were made with their approval. 
For the research to be credible and reliable, the volunteerism of the teachers was taken into account. Moreover, the consistency of the data obtained was ensured by confirming the teachers' answers to the questions. All the procedures and research process performed to increase the external validity of the study are given in the study in detail and all the data of the study are kept. To ensure the internal consistency of the study, no intervention was made and no comments were added to the answers given by the teachers to the interview questions. Also, the interview questions related to the sub-problems of the research were compared. Information on this is given in Table 2 below.

Table 2

Interview questions

\begin{tabular}{|c|c|}
\hline Research Question & Inteview Questions \\
\hline $\begin{array}{l}\text { 1. Is democracy education included in } \\
\text { education faculties? }\end{array}$ & $\begin{array}{l}\text { Did you get education about democracy education in your } \\
\text { university education? (If it took: content, duration,...) }\end{array}$ \\
\hline $\begin{array}{l}\text { 2. Is democracy education included in in- } \\
\text { service training? }\end{array}$ & $\begin{array}{l}\text { Have you ever received any in-service lessons, courses, etc. related } \\
\text { to democracy education? (If yes: content, duration, how and where } \\
\text { it was given...) }\end{array}$ \\
\hline \multirow[t]{3}{*}{$\begin{array}{l}\text { 3. Is democracy education included in the } \\
\text { primary school curriculum? }\end{array}$} & $\begin{array}{l}\text { How does the Education System raise the awareness of students } \\
\text { about democracy, democratic participation and personal rights? Can } \\
\text { you explain? }\end{array}$ \\
\hline & $\begin{array}{l}\text { How is democracy education included in school programs? Can you } \\
\text { explain? }\end{array}$ \\
\hline & $\begin{array}{l}\text { What is there about democracy education in the textbook and other } \\
\text { teaching materials? Can you give examples? }\end{array}$ \\
\hline $\begin{array}{l}\text { 4. What are the activities teachers do in } \\
\text { their lessons on democracy education? }\end{array}$ & $\begin{array}{l}\text { What kind of activities can children gain awareness of democracy in } \\
\text { the lesson? Can you give an example? }\end{array}$ \\
\hline \multirow[t]{4}{*}{$\begin{array}{l}\text { 5. What is done about democracy } \\
\text { education outside of the lesson? }\end{array}$} & $\begin{array}{l}\text { What can be done to raise awareness of democracy in students in } \\
\text { extracurricular activities? Can you give examples? }\end{array}$ \\
\hline & $\begin{array}{l}\text { Can family contribute to democracy education? Can you give } \\
\text { examples? }\end{array}$ \\
\hline & $\begin{array}{l}\text { How can the social environment and daily life contribute to } \\
\text { democracy education? Can you give examples? }\end{array}$ \\
\hline & $\begin{array}{l}\text { How can social media contribute to democracy education? Can you } \\
\text { give examples? }\end{array}$ \\
\hline \multirow{2}{*}{$\begin{array}{l}\text { 6. What are the examples of activities for } \\
\text { the democracy education framework } \\
\text { program? }\end{array}$} & $\begin{array}{l}\text { Could you have any suggestions for activities for our democracy } \\
\text { education activity program that we will prepare? }\end{array}$ \\
\hline & Is there anything you want to add? \\
\hline
\end{tabular}

Looking at Table 2, teachers were asked 1 question for the first, second and third sub-problems of the research, 3 questions for the third sub-problem, 6 questions for the fifth sub-problem, and 2 questions for the sixth sub-problem of the study.

\section{Data Analysis}

In the study, the descriptive analysis method, which is frequently used in qualitative research, was used to examine the opinions of teachers. The data obtained in the descriptive analysis are summarized and interpreted according to previously determined themes. Then, these descriptions are explained and interpreted, cause and effect relationships are examined, and some results are reached (Yildirım, Şimşek, 2016). The data obtained from the interview form were coded and analyzed in detail. In this study, before starting the analysis, the themes were determined by the researchers, taking into account the purpose of the study and the interview questions. Regarding each question, the answers given by the participants were processed according to these themes, a list was made, given in the findings and interpreted. In this way, the research was tried to be easy and understandable. Themes determined within the scope of the research; The availability of democracy education at the university, the 
inclusion of democracy education in in-service training, the inclusion of democracy education in the primary school curriculum, the activities teachers do in their courses on democracy education, the state of extra-curricular democracy education and the activity recommendations for the democracy education framework program.

Later, the data encoded by the researchers were confirmed by an academic expert in the field. With this confirmation, the credibility of the research was tried to be ensured. Yıldırım and Şimşek (2016) stated that taking expert opinions, using diversification, including more than one researcher in the process and including direct quotations in the studies will increase the credibility of the research. During the analysis process of the study, permission was obtained from the participants and a code number (in the form of T1, T2, T3,...) was given to the participants in line with ethical principles. In the descriptive analysis, in which the data obtained in the study are summarized and interpreted according to previously determined themes, direct quotations are included to reflect the views of the individuals participating in the interview (Yıldırım \& Şimşek, 2016). In this context, the findings were supported by direct quotations in order to reflect the views of the teachers who participated in the study clearly and clearly. To ensure the consistency of the research, the opinion of another researcher was also consulted in the distribution of the data to themes during the analysis process. The reliability formula [Reliability $=$ Consensus $/$ (Consensus + Disagreement)] suggested by Miles and Huberman (1994) was used to calculate consistency between data. As a result of the calculation, it was determined that the reliability of the research was over $80 \%$. The data obtained in the study have been archived for verifiability.

\section{FINDINGS}

In this section, primary school teachers' views on democracy education were discussed and the data obtained from teachers were tried to be given.

\section{Inclusion of Democracy Education in Education Faculty Programs}

Under this heading, findings on the inclusion of primary school teachers in democracy education in the university are given. The first sub-problem of the research; "Is there a place for democracy education at the university?" Regarding the question to the teachers; "Have you received training on democracy education in your university education? (If yes: content, duration,...) 'interview question was asked and all 15 teachers stated that they did not receive training. This situation is among the important findings obtained in the study. The opinions of the teachers on this subject are as follows.

"No." (T_5)

"No, I didn't." (T_8)

"No, I didn't get any education at the university." (T_13)

\section{Providing Democracy Education in In-Service pieces of training}

Under this heading, findings on whether primary school teachers receive democracy education through in-service training are included. The second sub-problem of the research; "Is democracy education included in in-service training?" Regarding the question to the teachers; "Have you ever received any in-service lessons, courses, etc. related to democracy education? (If yes: content, duration, how and where it was given...), the interview question was asked and all 15 teachers stated that they were not trained by the Ministry of Education. This situation is among the other important findings obtained in the study. The opinions of the teachers on this subject are as follows.

"No, I haven't received any training." (T_4)

"No." (T_9) 
"No, I have not received any in-service training by the ministry." (T_14)

Under this heading, findings on whether primary school teachers receive democracy education through in-service training are included. The second sub-problem of the research; "Is democracy education included in in-service training?" Regarding the question to the teachers; "Have you ever received any in-service lessons, courses, etc. related to democracy education? was asked and all 15 teachers stated that they were not trained by the Ministry of Education. This situation is among the other important findings obtained in the study. The opinions of the teachers on this subject are as follows.

"No, I haven't received any training." (T_4)

"No." (T_9)

"No, I have not received any in-service training by the ministry." (T_14)

\section{Inclusion of Democracy Education in Primary School Curriculum}

Under this heading, findings on the inclusion of primary school teachers in democracy education in our primary school education system are included. The third sub-problem of the research; "Is democracy education included in the primary school curriculum?" Teachers' opinions regarding the question are given in Table 3 below.

Table 3

Categories and codes regarding the inclusion of democracy education in the primary school curriculum Theme: Inclusion of democracy education in the primary school curriculum

\begin{tabular}{lll}
\hline Categories & Codes & $\mathrm{f}$ \\
\hline Democracy, Democratic Inclusion, Rights & Learning is individual & 12 \\
\cline { 2 - 3 } & A multidimensional classroom setting & 8 \\
\cline { 2 - 3 } & Class assemblies & 15 \\
\cline { 2 - 3 } & The stereotypical student model & 5 \\
\cline { 2 - 3 } & Bullying & 10 \\
\cline { 2 - 3 } & Awareness & 13 \\
\hline School Curricula & Class assemblies & 10 \\
\cline { 2 - 3 } & Decision-making process & 11 \\
\cline { 2 - 3 } Textbook and other teaching materials & Lecture, question answer, fill in the blank & 14 \\
\cline { 2 - 3 } & Case studies & 3 \\
\cline { 2 - 3 } & Events & 10 \\
\cline { 2 - 3 } & Life studies textbook & 3 \\
\cline { 2 - 3 } & Voting & 10 \\
\hline
\end{tabular}

As can be seen in Table 3, regarding the inclusion of democracy education in the primary school education system of primary school teachers under the category of "democracy, democratic participation, and personal rights", creating multi-faceted classroom environments where learning is individual, the creation of class councils, abandonment of stereotyped student models, They stated that countermeasures and awareness-raising activities about democracy were included.

Primary school teachers, regarding the inclusion of democracy education in the education system; regarding the category of "school programs"; They stated that school councils were formed, decisionmaking processes and activities such as narration, question-answer, and filling the gap.

Primary school teachers, regarding the inclusion of democracy education in the primary school education system; Regarding the category of "textbooks and other teaching materials"; They stated that democracy education is given with the help of information and visuals about case studies, activities and voting. In addition, the teachers stated that it is given through activities related to 
democracy education in the life studies textbook. It is a striking finding that the programs in our education system form a stereotypical student model. The opinions of the teachers on this subject are as follows.

"Not every child can learn in the same way. This can be overcome by adding the child's thoughts to the lesson and accepting them as an individual with a versatile classroom environment. The education system does not allow this. It cultivates a stereotypical student model. " (T_3)

"In the fourth grade, the book of the human rights and citizenship course is explained with case studies. Other grades are also included in the life studies textbook. " (T_12)

"Voting, our democratic rights, etc. topics are included. Lecture, question and answer, fill in the blank, etc. it is also reinforced in the way. " (T_11)

\section{Activities Teachers Perform in their Lessons Related to Democracy Education}

Under this heading, findings of the activities that primary school teachers do in their classes to raise awareness of democracy are included. The research has four sub-problems; "What are the activities teachers do in their lessons about democracy education?" Teachers' views regarding the question are given in Table 4 below.

Table 4

Categories and codes related to the activities teachers do in their lessons on democracy education Theme: Activities teachers do in their lessons on democracy education

\begin{tabular}{lll}
\hline Categories & Codes & $\mathrm{f}$ \\
\hline Activities in the courses & Ballot box & 11 \\
\cline { 2 - 3 } & Animation & 14 \\
\cline { 2 - 3 } & Drama, watching videos & 5 \\
\cline { 2 - 3 } & Respecting the decisions & 7 \\
\cline { 2 - 3 } & Self-confidence and respect & 12 \\
\cline { 2 - 3 } & Class majority & 15 \\
\cline { 2 - 3 } & School student assembly election & 15 \\
\cline { 2 - 3 } & Encouragement & 13 \\
\cline { 2 - 3 } & Conducting research & 14 \\
\cline { 2 - 3 } & Class representative & 12 \\
\hline
\end{tabular}

In Table 4, to raise awareness of democracy in primary school teachers; Regarding the category of "done in the lesson", they stated that they set up ballot boxes within the scope of the lesson in their classrooms, they did role-play activities related to democracy, they did drama, video watching, activities to improve students' self-esteem and confidence, and they established classroom rules according to the decision of the majority of the class. In addition, primary school teachers, in order to gain the awareness of democracy in their classrooms; They stated that they guide their students in the elections of the school student council, encourage democratic behavior, enable them to do research on the concepts of democracy and human rights, and elect class representatives to participate in the election of the school assembly. Developing self-confidence and respect in students and ensuring that decisions are respected are remarkable codes in the research. The opinions of the teachers on this subject are as follows.

"Drama can be gained through activities such as video watching." (T_4)

"With the ballot box, voting can be animated by reducing it to class level. A voting environment can be created in the classroom. Individuals who cannot vote can also be kept aside by means of animation. Thus, those who do not vote will be taught. " (T_7) 
"We should respect the decisions of children and see them as individuals with self-confidence and self-respect. Let the class president choose themselves, act according to the decision of the majority, etc. " (T_13)

\section{Democracy Education Outside of Classes}

Under this heading, findings about the state of primary school teachers' democracy education outside the classroom are given. The fifth sub-problem of the research; "What is done about democracy education outside of the classroom?" Teachers' views regarding the question are given in Table 5 below

Table 5

The categories related to the extracurricular democracy education activities

\begin{tabular}{lll}
\hline Tema: Ders dişında demokrasi eğitiminin yapılma durumu & $\mathrm{f}$ \\
\hline Categories & Codes & 11 \\
\hline Extracurricular activities & Field trips & 13 \\
\cline { 2 - 3 } & Project works & 12 \\
\cline { 2 - 3 } & Abstract concepts & 15 \\
\cline { 2 - 3 } & Concrete concepts & 9 \\
\cline { 2 - 3 } & Decision & 11 \\
\hline Family contribution & No family contribution & 13 \\
\cline { 2 - 3 } & Family contribution & 14 \\
\cline { 2 - 3 } & Student ideas & 12 \\
\hline Social setting and daily routines & Deciding together & 11 \\
\cline { 2 - 3 } & Daily routines & 9 \\
\cline { 2 - 3 } & Right to speak & 15 \\
\cline { 2 - 3 } & Implementation & 13 \\
\hline Social Media & Watching news & 12 \\
\cline { 2 - 3 } & Reinforcement & 14 \\
\cline { 2 - 3 } & Polls & 14 \\
\cline { 2 - 3 } & Voice of the majority \\
\cline { 2 - 3 } & Learning by seeing & 14 \\
\hline
\end{tabular}

As can be seen in Table 5, primary school teachers regarding democracy education, related to the "extracurricular activities" category; They stated that it is necessary to organize a parliamentary trip with the students, to assign them project assignments, to focus on concrete concepts rather than abstract concepts, and to ensure that students take an active role in the decision-making process.

Primary school teachers, regarding democracy education, regarding the category of "family contribution"; They stated that although the family contribution to democracy education is too much, the family does not contribute and the ideas of the students are ignored in the family. It is a striking finding in this study that families should be more sensitive about democracy education.

Regarding democracy education, primary school teachers, in the category of "social environment and daily life"; They stated that in the decision-making process, decision-making mechanisms with the society should be taken and young people should be given a voice in social life.

Primary school teachers, regarding democracy education, regarding the "social media" category; They stated that the voice of the majority is important and should be treated accordingly. This situation also 
creates democratic living standards. Besides, in this category; "News monitoring", "reinforcement", "survey" and "learning by seeing" statements were other striking codes. The opinions of the teachers on this subject are as follows.

"The events they experience in their daily life and those who follow them can also get information on this subject. They can grasp what they live in a democratic environment as having a say in the first family, or they can realize this deficiency by not being given any right to speak ". (T_1)

"Do not decide jointly for dinner, decide the place to go on vacation together or do not obey the decision of the majority." (T_9)

"A visit to the assembly can be made and it can be helped to translate the abstract thoughts of the student into the concrete. An environment of democracy can be created in the classroom. " (T_8)

"The child's opinion is not taken on issues that concern students as a family. it should be taken." (T_15)

"They can watch news on this subject and get information on social media programs. They can learn whether they know what they know or not. " (T_2)

\section{Examples of Activities for Democracy Education Framework Program}

Under this title, examples of activities for the democracy education framework program of primary school teachers are included. The sixth sub-problem of the research; "What are the examples of activities for the democracy education framework program?" Teachers' views regarding the question are given in Table 6 below.

Table 6

Categories and codes for examples of activities for democracy education framework program Theme: Examples of activities for democracy education framework program

\begin{tabular}{lll}
\hline Categories & Codes & $\mathrm{f}$ \\
\hline Activity Programme & Learning by doing & 15 \\
\cline { 2 - 3 } & Learning by seeing & 14 \\
\cline { 2 - 3 } & Drama in the classroom & 10 \\
\cline { 2 - 3 } & Case studies & 12 \\
\cline { 2 - 3 } & Discussion activities & 13 \\
\cline { 2 - 3 } & Competitions & 11 \\
\cline { 2 - 3 } & Sport Activities & 9 \\
\cline { 2 - 2 } & Selection of classroom representative & 15 \\
\hline
\end{tabular}

In Table 6, regarding the democracy education of primary school teachers, regarding the "activity program" category; They stated that students should learn by doing and experience and democratic life skills should be seen. In addition, teachers stated that democratic consciousness will be brought to the students in the classroom or school environment with activities such as dramas, case studies, discussions, debates, organizing competitions, sports activities and class president elections. Learning by doing and experiencing and class president elections are remarkable codes. The opinions of the teachers on this subject are as follows.

"Learning by doing can be education by seeing." (T_10)

"In order to raise the awareness of democracy to the students in my class, I first create environments where they can have a say. For example, I make class president elections once a month and I make this behavior happen to my students. " (S_15)

"By having students make dramas in the classroom, behaviors such as sharing and expressing their opinions can be gained. (Ö_4) 
"A student can be asked to tell his / her friends about a case study that he had with a friend in another class. In this way, other students learn how to communicate with others based on this case study. " (Ö_7)

"As a teacher, I set a discussion topic for students in my classroom so that they can demonstrate democratic behavior. I divide the students in my class into groups so that this topic can be discussed. Each group concludes by discussing the subject. This teaches students to respect the opinions of others. In this way, I gain a democratic awareness. " (Ö_13)

"I organize competitions to raise awareness of democracy in my students." (S_5)

\section{DISCUSSION AND CONCLUSION}

The opinions of primary school teachers and suggestions for implementation regarding democracy education in primary schools are included in this section.

The teachers interviewed stated that they did not receive any training for democracy education in university education. In today's era when it is so important to gain awareness of democracy at an early age, it is important to give lessons for democracy education especially in faculties that train teachers (Ersoy, 2007; Hotaman, 2010; Theisen, 2002). In addition, the participating teachers were not provided with training that could transfer democracy education to students through in-service training. However, it is known that in-service training that increase the knowledge, skills and abilities of teachers are effective in the process of being a teacher candidate after being appointed as a teacher (Gürşimşek \& Göregenli, 2004; Sağlam, 2011).

According to the results of the interviews with the teachers, we see that individual learning, multiclassroom environment, democracy awareness, democratic behavior and human rights are mentioned regarding the activities in democracy education. In addition, the inadequacy of activities related to democracy education is mentioned in the textbooks. In this context, it is necessary to include information, activities and learning environments that will develop democratic consciousness in students in the textbooks used in primary schools (Harber, 2002; Özdemir, 1998). In addition, students should be given the behavior of living and sharing (Rawitch, 1991; Tourain, 2002).

Primary school teachers stated that they established a ballot box to elect a class president in their classes to raise awareness of democracy, developed students' self-confidence and respect, and reinforced the behavior of respecting decisions. Although these activities that teachers have done in their classrooms are appropriate, it can be said that they are insufficient in developing the democracy education of students. Morris and Cogan $(2011, \mathrm{p}$.118) stated that it is very important to raise students' awareness of democracy, they have to gain this acquisition at an early age, and teachers have a lot of work in this process. In this context, it can be stated that more activities and concrete experiences should be offered. In his study, Ersoy (2016, p.81) concluded that democracy education should be expanded in primary education programs and divided into each grade level, its content should be renewed according to citizenship competencies, students' interest and readiness levels, studentcentered education approaches should be applied and teachers should be informed with in-service seminars. Gainor (2001) stated that gaining the awareness of democracy in primary schools is effective. In this context, it can be said that the positive behaviors of the students in the classroom in line with the democratic consciousness should be reinforced (Davis, 2003).

In the interview, activity suggestions of primary school teachers regarding democracy education; They have been concrete activities that students can understand, can be gained by means of animation, can be seen by trip-observation, can be applied in daily life, give children the right to speak, and give them the ability to decide together. As Gözütok (2007) stated, more activities should be included in teachers' classrooms, schools and the environment they live in for democracy education. Hotaman 
(2009) and Ravitch (1991) stated that the consciousness of democracy is learned not only with course subjects, but also through the absorption of the basic features of democracy and by practicing in a school environment with a democracy culture. In this context, it can be said that the method of learning by doing-experiencing should be applied to gain students' awareness of democracy.

In the study, it is seen that the current democracy education in primary schools is not sufficient according to the opinions of the teachers. However, considering the necessity of democracy education to gain students their rights and freedoms, this situation should be corrected as soon as possible. As a matter of fact, when we look at the studies on democracy education, the importance of democratic education is emphasized (Biesta, 2007; Crick, 1998; Edward, Giacomo, \& Andrei, 2006; Farrell, 1998, Gerzon, 1997; Kepenekçi, 2003; Kuş, 2012). It can be said that it would be beneficial to rearrange textbooks, educational programs, in-class and out-of-class activities for democracy education.

In the study, teachers suggested that a separate course be given under the name of democracy education in universities, especially in education faculties. Teachers requested that in-service training be organized by the Ministry of National Education regarding democracy education. In the study, the participants stated that concrete activities from daily life should be included in education programs, textbooks and other educational materials for democracy education. Apart from this, it can be said that teachers should give more place to democracy education in their classrooms and schools. In addition, it may be suggested that the ministries of education of countries support democracy education with a project, trip or observation in order to present concrete experiences for students in democracy education.

This research was conducted with teachers who teach at primary school level. In this context, it can be suggested that a different study should be conducted in primary, secondary and high school levels by expanding the scope of the research. In addition, by examining the textbooks used in primary schools in detail, activities for democracy education can be examined.

\section{REFERENCES}

Biesta, G. (2007). Education and the democratic person: Toward a political conception of democratic education. Teachers College Record, 109(3), 740-69.

Blair, H. (2003). Jump - Starting Democrcy: Adult civic education and democratic participation in three countries. Democratization, 10(1), 53-76.

Büyüköztürk, Ş., Kılıç Çakmak, E., Akgün, Ö. E., Karadeniz, Ş. ve Demirel, F. (2009). Bilimsel araştırma yöntemleri (Scientific research methods). Ankara: Pegem Publishing.

Bogdan, R. C., \& Biklen, S. K. (1992). Qualitative research for education: An introduction to theory and methods. USA: Allyn and Bacon.

Carlson, D. (2005). Hope without illusion: Telling the story of democratic educational renewal. International Journal of Qualitative Studies in Education, 18(1), 21-45.

Crick, B. (1998). Education for Citizenship and the teaching of democracy in schools: Final Report of the Advisory Group on Citizenship, QCA: London.

Cohen, L. Manion, L. \& Morrison, K. (2007). Research methods in education (6th ed.). New York, NY: Routledge.

Davis, O.L., (2003). Editorial does democracy in education stillive. Journal of Cumculum an Supervision, 19(1), 1-4. 
Dewey, J. (1996). Democracy and education: An introduction to the philosophy of education. New York: The Free Press.

Edward L. G., Giacomo P. \& Andrei S. (2006). Why does democracy need education?. NBER Working Paper No. 12128.

Ersoy, A. F. (2007). Teachers' views on effective citizenship education practices in social studies course. Unpublished doctoral dissertation, Anadolu University, Institute of Educational Sciences, Eskişehir.

Ersoy, A. F. (2016). Vatandaşlık ve demokrasi eğitimi dersine ilişkin sosyal bilgiler öğretmenleri ve öğrencilerinin algısı (Social Studies Teachers' and Students' Perception of the Citizenship and Democracy Education Course). Inönü University Journal of the Faculty of Education, 17(3), 67-83. DOI: $10.17679 /$ iuefd.17345163

Farrell, J. P. (1998). Democracy and education: Who gets to speak and who is listened to?. Curriculum Inquiry, 28(1), 1-7.

Gainor, L. (2001). Effective Student Government in The Elemantary School. Education, 94(2), 129131.

Gerzon, M. (1997). Teaching democracy by doing it!. Educational Leadership, 54(5), 6-11.

Grix, J. (2010). The Foundations Of Research. London: Palgrave Macmillan.

Gözütok, D. (2007). Öğretim ilke ve yöntemleri (Teaching principles and methods). Ekinoks Publishing. Ankara.

Gürşimşek, I. ve Göregenli, M. (2004). Öğretmen adayları ve öğretmenlerde demokratik tutumlar, değerler ve demokrasiye ilişkin inançlar (Democratic attitudes, values and beliefs about democracy in prospective teachers and teachers). Proceedings of the 1st International Symposium on Democracy Education (77- 85). 20-21 May 2004, Çanakkale: Çanakkale Onsekiz Mart University Publishing.

Harber, C., (2002). Education, democracy and poverty reduction in Afrika. Comparative Education, $38(3), 267-276$.

Hotaman, D.(2009). Demokratik ĕgitim: demokratik bir ĕgitim programı (Democratic education: a democratic educational program). Kincal, R. (Editör) 11-12 June 2009, Internationel Symposium On Democracy Edutacion In Europe Proceedings, (474-485). Ankara: Nobel Publishing.

Kepenekçi, Y. K. (2003). Demokratik okul (Democratic school). Journal of Educational Research, $3(11), 44-53$.

Kuş, Z. (2012). Exploring of middle school students? democracy perceptions according to different variables. Unpublished doctoral dissertation. Gazi University Institute of Educational Sciences, Ankara.

Levin, B. (1998). The educational requirement for democracy. Curriculum Inquiry, 28(1), 57-79.

Liamputtong, P. (2013). Qualitative research methods (4th ed.). South Melbourne: Oxford University Press.

Miles, M. B. \& Huberman, A. M. (1994). Qualitative data analysis: An expanded sourcebook. New York: Sage.

Ministry of Education [MEB], (2015). Primary school human rights, citizenship and democracy course curriculum. Ministry of Education Publications. Ankara. 
Morin, E., (2006). Geleceğin eğitimi için gerekli yedi bilgi. İstanbul: İstanbul Bilgi Üniversitesi Yayınları 21, 2. bask1.

Morris, P. ve Cogan J. (2001). A comparative overview: civic education across six societies. International Journal of Educational Research, 35, 109-123.

Morgan, D. L. \& Morgan, R. K. (2008). Single-Case research methods for the behavioral and health sciences. SAGE Publications.

Neuman, L. W. (2014). Social research methods: Qualitative and quantitative approaches (Seventh Ed.). Essex: Pearson Education Limited.

Neuman, W. L. \& Robson, K. (2014). Basics of social research. Toronto: Pearson Canada.

Özdemir, M. (1998). Hayat bilgisi ögrenme ve ögretme etkinlikleri (Life studies learning and teaching activities). Pegem Ppublishing.

Ravitch, D. (1991). Democracy: What it is and how to teach 1t. Social Studies, 82(2), 49-55.

Richardson, R. (1979). Learning in a world of change: Methods and Approaches in the Classroom, Unesco.

Sağlam, H. İ. (2011). Öğretmen adaylarının etkili vatandaşlık yeterlik düzeyleri (Proficiency levels of student teachers effective citizenship). Kastamonu University Kastamonu Journal of Education, 19(1), 39-50.

Scweisfurth, M. (2002). Democracy and teacher education:Negotiating practice in the Gambia. Comparative Education, 38(3), 303-314.

Tavşancıl, E. ve Aslan, E. (2001). İ̧̧erik analizi ve uygulama örnekleri (Content analysis and application examples). Epsilon Publishing.

Theisen, R. (2002). Modeling democracy in student governance after 9/11. The Education Digest, 67, $18-23$.

Travers, M. (2001). Qualitative research through case studies. Sage.

Tourain, A. (2002). Demokrasi nedir (What is democracy?)? Liberte Publishing.

Yıldırım, A. ve Şimşek, H. (2016). Sosyal bilimlerde nitel araştırma yöntemleri (Qualitative research methods in the social sciences). Seçkin Publishing.

Yıldırım, A. (1999). Nitel araştırma yöntemlerinin temel özellikleri ve eğitim araştırmalarındaki yeri ve önemi (Basic features of qualitative research methods and their place and importance in educational research). Education and Science, 112, 1300-1337. 